\title{
Case of Eccrine hidrocystoma of the vulva
}

\author{
Susan W. Lipinski, ${ }^{1}$ Mackenzie Treloar $^{2}$
}

Keywords: Eccrine hidrocystoma, vulvar lesions, cutaneous neoplasms, eccrine glands

\begin{abstract}
Objective: Eccrine hidrocystomas are benign cystic lesions that are very rare; their presence on the vulva is extraordinarily rare. We present a woman with a solitary eccrine hidrocystoma of the vulva.
\end{abstract}

Case: A 36-year-old woman presented with a six month history of an asymptomatic and enlarging blue-black lesion on the left labia. The histopathological diagnosis after excision was eccrine hidrocystoma. After removal, she had complete healing of the site and did not require any further intervention.

Conclusions: Eccrine hidrocystomas are benign tumors. Their clinical presentation on the vulva can mimic other benign or malignant lesions, therefore biopsy and histological evaluation is necessary.

${ }^{1}$ Partners in Obstetrics and Gynecology, Waterloo, lowa

${ }^{2}$ University of lowa Carver College of Medicine, lowa City, lowa

\section{Introduction}

Eccrine hidrocystomas are rare, benign tumors of the sweat glands that predominantly arise on the face and neck. These dome-shaped, cystic lesions present with a dark blue color and range from 1-6 $\mathrm{mm}$ in diameter. Usually a solitary lesion, eccrine hidrocystomas, occur in men and women with similar frequency and most often present between 30-70 years of age. ${ }^{1-4}$ Although eccrine sweat glands are distributed on almost all areas of the body, including the vulva, it is unclear why eccrine hidrocystomas rarely affect regions other than the head and neck; very few vulvar lesions have been reported. ${ }^{1}$ We present a case of eccrine hidrocystoma occurring on the vulva of a healthy 36 year-old female.

\section{Case report}

A 36-year-old female, gravida 2 para 2, presented with a six month history of a slowly enlarging blue-black lesion on the left labia majora. At initial evaluation it was described by the outside physician as $2 \mathrm{~mm}$ in size and diagnosed as a

Please cite this paper as: Lipinski SW, Treloar M. Case of Eccrine hidrocystoma of the vulva. Proc Obstet Gynecol. 2016;6(1): Article 3 [ 4 p.]. Available from: http://ir.uiowa.edu/pog/ Free full text article.

Corresponding author: Susan W. Lipinski, MD, Partners in Obstetrics and Gynecology, Waterloo, Iowa, USA. Telephone: 319-530-744. slipinski@waterlooobgyn.com

Financial Disclosure: The authors report no conflict of interest.

Received: 21 January 2016; accepted 22 February 2016; POG in Press, 3 March 2016

Copyright: (c) 2016 Lipinski et al. This is an open-access article distributed under the terms of the Creative Commons Attribution License, which permits unrestricted use, distribution, and reproduction in any medium, provided the original author and source are credited. 
benign vulvar varicosity. After 3 months it had grown to $4 \mathrm{~mm}$ and was accompanied by a $2 \mathrm{~cm}$ palpable lymph node in the left groin; therefore, she was referred for gynecologic evaluation and biopsy. She denied any associated symptoms. Her past medical history was otherwise unremarkable and she had no family history of skin cancer or melanoma, nor any other skin conditions.

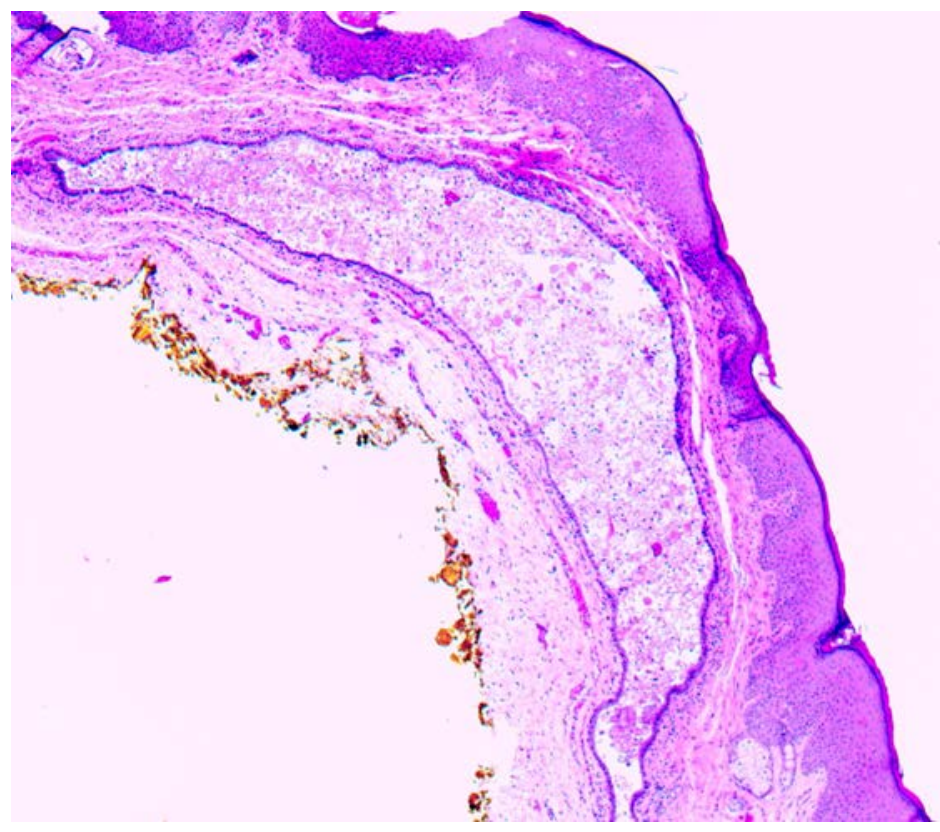

Figure 1. Histology of eccrine hidrocystoma: a solitary cystic lesion present in the dermis.

Exam revealed a $4 \mathrm{~mm}$ dome-shaped, blue-black lesion with distinct edges. The lesion did not blanch and was not tender. A $4 \mathrm{~mm}$ punch was used to excise the lesion entirely. Pathology evaluation showed an eccrine hidrocystoma (Figures 1 and 2). After removal she had complete healing of the biopsy site and resolution of the left inguinal lymph node.

\section{Discussion}

A review of the literature revealed very few references to vulvar eccrine hidrocystomas in particular with only one case report in a 47 year-old healthy Japanese woman. $^{1}$ Vulvar eccrine hidrocystomas are rare findings that may be mistaken for other cystic and pigmented lesions; such as melanoma, blue nevi, pigmented basal cell carcinoma, and pyogenic granulomas. In this case the initial provider mistook the lesion for a vulvar varicosity. Melanoma of the vulva is a rare malignancy but does represent $8-10 \%$ of all vulvar malignancies ${ }^{5}$ and should be considered when evaluating pigmented vulvar lesions.

Any clinically suspicious vulvar lesion 
should be biopsied, marked for orientation, and submitted for pathologic evaluation. Histologically, eccrine hidrocystomas are cysts with a single cavity usually composed of two layers of cuboidal cells located within the middermal to epidermal layers of skin. ${ }^{2}$ It is thought that these lesions develop from dilation of blocked eccrine sweat glands. ${ }^{1}$ While eccrine sweat glands are abundantly present on the vulva, it is unknown why eccrine hidrocystomas rarely develop in this area.

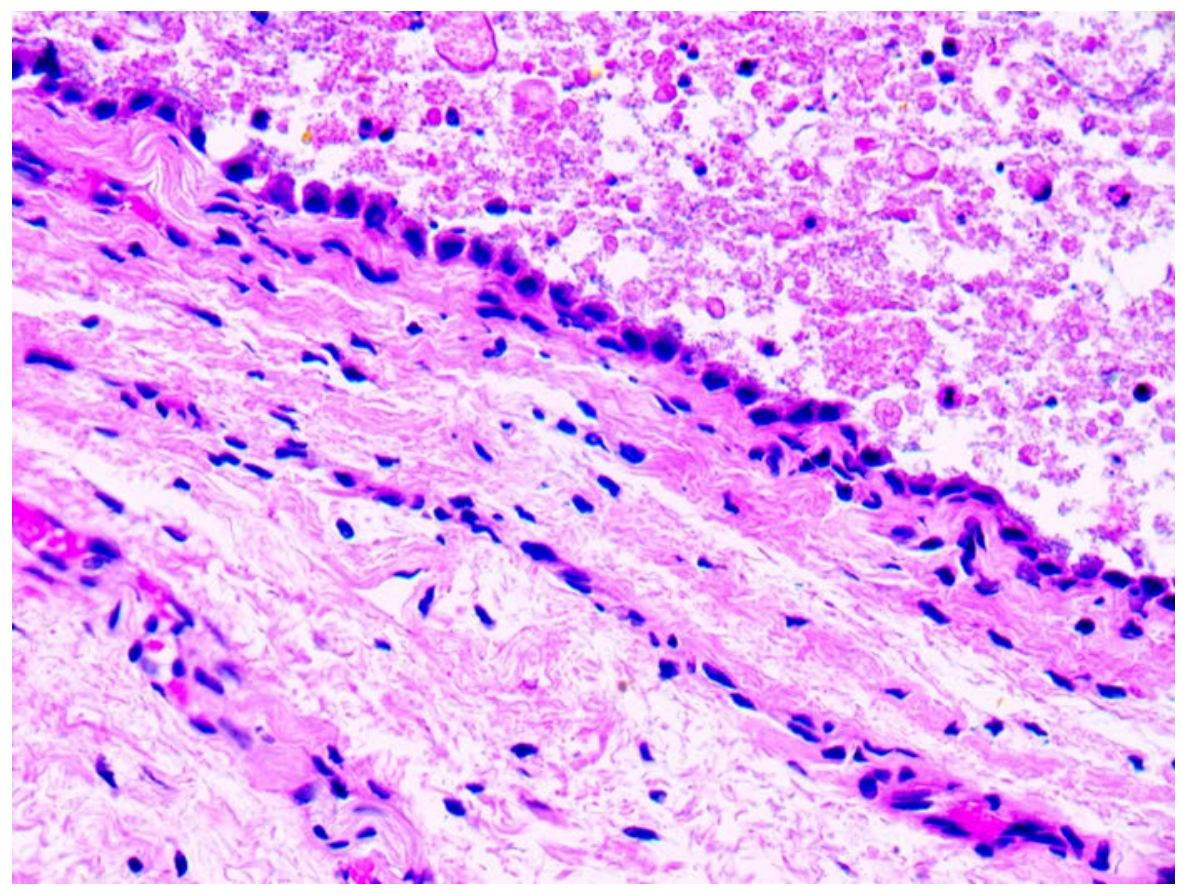

Figure 2. Histology of eccrine hidrocystoma: cyst lined by a single layer of cuboidal epithelium.

Treatment options for eccrine hidrocystoma are similar to that of other vulvar lesions, expectant management versus excision versus obliterative procedures. Given that definitive diagnosis is necessary to exclude malignant pathology; initial evaluation should include biopsy which may occur as a complete and curative excisional procedure of a small lesion. However, if multiple lesions exist an obliterative procedure can follow; options described in the literature include needle drainage, injection of topical 1\% atropine, scopolamine creams, electrodesiccation, and laser treatment. ${ }^{2-4}$

\section{Conclusion}

Vulvar eccrine hidrocystomas are benign tumors of the eccrine sweat 
glands. Clinical presentation can mimic other benign or malignant vulvar lesions; therefore biopsy and histological evaluation are necessary prior to any other treatment.

\section{References}

1. Kamishima $\mathrm{T}$, Igarashi $\mathrm{S}$, Takeuchi $\mathrm{Y}$, Ito $M$, Fukuda $T$. Pigmented hidrocystoma of the eccrine secretory coil in the vulva: clinicopathologic, immunohistochemical and ultrastructural studies. J Cutan Pathol. 1999 Mar;26(3):145-9. http://dx.doi.org/10.1111/j.16000560.1999.tb01819.x PubMed PMID: 10235380.

2. Sarabi K, Khachemoune $A$. Hidrocystomas--a brief review. MedGenMed. 2006 Sep 6;8(3):57. Review. PubMed PMID: 17406184.

3. Ozkan Z. Multiple eccrine hidrocystomas of the vulva. Int $\mathrm{J}$ Gynaecol Obstet. 2009 Apr;105(1):65. http://dx.doi.org/10.1016/j.ijgo.2008.11.0 09 Epub 2008 Dec 25. PubMed PMID: 19110246.

4. Obaidat NA, Alsaad KO, Ghazarian D. Skin adnexal neoplasms--part 2: an approach to tumours of cutaneous sweat glands. J Clin Pathol. 2007 Feb;60(2):145-59. Epub 2006 Aug 1. http://dx.doi.org/10.1136/jcp.2006.04160 8 PubMed PMID: 16882695.

5. Irvin WP Jr, Legallo RL, Stoler MH, Rice LW, Taylor PT Jr, Andersen WA. Vulvar melanoma: a retrospective analysis and literature review. Gynecol Oncol. 2001 Dec;83(3):457-65.

http://dx.doi.org/10.1006/gyno.2001.633

7 PubMed PMID: 11733955. 